\title{
Pakistan's Cold War(s) and International Law
}

\author{
VANJA HAMZIĆ
}

\section{Introduction}

Dear Uncle,

Greetings! This letter comes to you from your Pakistani nephew whom you do not know, nor does anyone else in your land of seven freedoms.

You should know why my country, sliced away from India, came into being and gained independence, which is why I am taking the liberty of writing to you. Like my country, I too have become independent and in exactly the same way. Uncle, I will not labour the point since an all-knowing seer like you can well imagine the freedom a bird whose wings have been clipped can enjoy. ...

My country is poor. It has no art paper, nor proper printing presses. I am living evidence of this poverty. You will not believe it, uncle, but despite being the author of twenty-two books, I do not have my own house to live in. And you will be astonished to know that I have no means of getting myself from one place to the other. I neither have a Packard nor a Dodge; I do not even have a used car. ... You will certainly ask me out of astonishment why my country is poor when it boasts of so many Packards, Buicks and Max Factor cosmetics. That is indeed so, uncle, but I will not answer your question because, if you look into your heart, you will find the answer there (unless you have had your heart taken out by one of your brilliant surgeons).

That section of my country's population which rides in Packards and Buicks is really not of my country. Where poor people like me and those even poorer live, that is my country. ${ }^{1}$

\footnotetext{
Email: vh1@soas.ac.uk. The author is immensely grateful to the entire Cold War International Law dream team for creating and maintaining an outstanding space for exchange, learning and mutual appreciation throughout the long transnational journey that has led to this publication. The present chapter owes much to that unique space and, especially, to the abiding intellectual generosity of Professor Sundhya Pahuja and Dr Safet HadžiMuhamedović. Thank you all!

1 Saadat Hasan Manto, 'First Letter to Uncle Sam' in Letters to Uncle Sam Hasan Khalid trans. (Alhamra Printing, 2001) 15-16. For the letter in its original language, see Saadat Hasan Manto, Manto Rama (Sang-e-Meel, 1990) 356-7.
} 
Thus wrote, at 'his perspicacious best', 2 the unparalleled Urdu short story writer and enfant terrible, Saadat Hasan Manto, in the first in a series of his fictitious letters to Uncle Sam in December 1951. Sardonic and plaintive about Pakistan's post-partition fate - epitomised by the new country's elites riding in their flashy American cars toward an ever-closer political, military and economic alliance with Uncle Sam - Manto's letter perfectly captures the Zeitgeist of rancour that Pakistan's left-leaning intelligentsia felt and expressed at the state of the country's class-cumpolitical affairs in the early years of the global Cold War. Depressed and broke, facing an 'obscenity' charge, Manto wrote the letter several days before 'being readmitted to the anti-alcoholic ward of the mental hospital'. ${ }^{3}$ Having, as the letter bitterly portends, become 'independent' and in exactly the same way as his country, the writer saw his own poverty and hopelessness as a true reflection of the direction his society had taken in the years immediately following the carnage of 1947 partition of the British Raj into the sovereign states of India and Pakistan.

The year in which Manto wrote the letter was not an ordinary one. Several months earlier, in February and March 1951, Pakistan's government charged several of its high-ranking military officials, as well as two members of the central committee of the Communist Party of Pakistan, Mohammad Ata and Sajjad Zaheer, of sedition and of planning a Sovietbacked coup d'état. Despite flimsy evidence against the alleged plotters, this case, popularly named the Rawalpindi Conspiracy, ${ }^{4}$ impelled the state to unleash a wide-ranging clampdown on Pakistan's prominent leftists, including the luminary Faiz Ahmed Faiz, often described as 'one of Pakistan's greatest poets'. ${ }^{5}$ Later the same year, Pakistan's first Prime Minister, Liaquat Ali Khan, was assassinated in an unrelated attack.

These events plunged Pakistan into a deep political turmoil and greatly influenced its future class relations and ideological orientation, which, in turn, reflected its never-quite-smooth sailing on the high seas of the global Cold War. On the one hand, the near-evisceration of the country's

2 Ayesha Jalal, The Pity of Partition: Manto's Life, Times, and Work across the IndiaPakistan Divide (Princeton University Press, 2011) 189-90.

3 Ibid., 190.

${ }^{4}$ For an excellent analysis of the Rawalpindi Conspiracy, see Kamran Asdar Ali, Communism in Pakistan: Politics and Class Activism 1947-1972 (I. B. Tauris, 2015) 114-43.

5 See, e.g., 'Remembering Faiz' (Staff Report), Dawn (3 February 2012) http://forum dawn.com/2011/02/13/the-current-debate-remembering-faiz/. 
Left made it a weak spot for the elaborate British and American intelligence networks operating within and without its territorial borders. ${ }^{6}$ The security void caused by the Prime Minister's assassination, on the other hand, marked the beginning of Pakistan's long evolution toward an artful messianic state, later dubbed the 'Muslim Zion' for its pretence of making the observance of Islam a national and nation-making affair par excellence. ${ }^{7}$

Taking the 1951 annus horribilis as a point of rupture, this chapter seeks to illuminate the political and legal developments bringing the once-neutral and non-aligned Pakistan firmly into Uncle Sam's Cold War embrace. Against a great deal of contemporary Cold War scholarship, I argue that Pakistan's complex relations with the United States - as well as with the Soviet Union, China, India and Afghanistan (each briefly examined in the present text) - place it firmly at the centre of global Cold War politics. That this was not immediately apparent to many a Cold War analyst should come as no surprise; rather, it attests to the deceptive nature of Cold War international relations, shrouded in secrecy, backroom dealing and ideologically ambiguous manoeuvres. In these affairs, Third World countries such as Pakistan often played a decisive role - but that role had to remain hidden for a variety of reasons, including that of the essential Cold War mythopoeia based on 'the balance of powers' between the Western and Eastern blocs. What's more, as a curious site of many a 'cold' and 'warm' regional war since its very inception, including those occurring well after the supposed end of the global Cold War, Pakistan's story to date is one of seemingly infinite warfare and political instability. I contend that this story is a reflection of the state's continuous internal political (and, particularly, class) struggle as well as its early lessthan-successful attempts to excel in Cold War international lawfare ${ }^{8}$ in

${ }^{6}$ The British Foreign Office collections on Pakistan and India, 1947-64, represent a rich archival source for studying secret diplomatic correspondence relative, in particular, to the British preoccupation with closely monitoring Pakistan's political Left and labour movements. In the early days of the Cold War, the gathered intelligence was regularly shared with the CIA and the US State Department. For an introductory text, see William Gould, 'The Changing Dynamics of Indian and Pakistani Society: State, Politics and Commonwealth' (Archives Direct, 2011) www.archivesdirect.amdigital.co.uk/Essays/Gould\#_ftn55.

7 See generally Faisal Devji, Muslim Zion: Pakistan as a Political Idea (Hurst \& Co, 2013). See also Vanja Hamzić, 'Review of Faisal Devji, Muslim Zion: Pakistan as a Political Idea' (2016) 36 South Asia Research 288; Jakob Rösel, 'Pakistan: Kunststaat, Militärstaat und Krisenstaat' (2009) 40 Internationales Asienforum 255.

${ }^{8}$ While the term 'lawfare' warrants caution, given its recent surge in right-wing scholarship, I find its basic definition, denoting the use of law as a weapon of war, salient and worth 'reclaiming', particularly for studies of Cold War international law. 
which its neighbouring states and the two global superpowers have arguably been more successful.

To illustrate this point, this chapter revisits some Cold War 'questions', or sites of regional political and legal importance, such as those of Kashmir, Jammu and Khyber Pakhtunkhwa ('Pashtunistan'), as well as the quintessential Third World spaces of (anti-)Cold War legal and political struggle, such as the international conferences in Bandung (1955) and Havana (1966). I argue that the (often idiosyncratic) interventions of Pakistan's diplomats and international lawyers in these sites form a distinct legal and political trajectory, which is at odds with the arbitrary, yet ubiquitous, conceptual delineations between 'cold' and 'warm' wars. Far from being peripheral to global Cold War developments, Pakistan's internal and international relations and troubles provide a rich source of strategies and ideas about the state, law and society in the Third World. They are, however, also a testament to the centrality of class struggle in a post-colony a struggle, exemplified in the events of 1951, that no lawfare could bring to an end.

\section{Pakistan's Search for a Place in Early Cold War Geographies}

Fraught as it is with its many definitional contests, ${ }^{9}$ the bulk of Cold War scholarship emanating from the former Western bloc has failed to engage substantially with the world regions it deemed only tangentially important to global geopolitical wrangles that had shaped and shaken the Cold War strata. We are often told, for example, that South Asia figured very little in early Cold War imaginaries, except perhaps as a distant 'Oriental' terra incognita. Thus, the remark of a New York congressman, on the eve of the partition of the British Raj, suggesting that 'most Americans still think of India as a land of minarets and performers of the rope-trick', seems to an influential Cold War historian 'hardly exaggerated'. ${ }^{10}$ In such narratives, Pakistan is routinely regarded as a case study for Cold War suzerainties in the Third World, for its unlikely ability to 'charm' (to its own detriment) a global superpower and, in a relatively short period of

9 See, e.g., Odd Arne Westad, 'The Cold War and the International History of the Twentieth Century' in Melvyn P. Leffler and Odd Arne Westad (eds.), The Cambridge History of the Cold War: Volume 1 - Origins (Cambridge University Press, 2010) 1.

${ }^{10}$ Robert J. McMahon, 'US Policy toward South Asia and Tibet during the Early Cold War' (2006) 8(3) Journal of Cold War Studies 131, 132. 
time, become 'America's most allied ally in Asia'. ${ }^{11}$ However, a closer look to the early days of both the Cold War and Pakistan's existence as an independent state reveals a much more complex and intriguing picture.

Despite their ability to appeal to 'landowners, businessmen, lawyers, socialists, intellectuals and the middle classes ${ }^{12}$ in the call for the creation of Pakistan, Mohammad Ali Jinnah and the Muslim League 'made governing the new state a matter of political gamesmanship where the party officials continued to manipulate colonial laws and legal procedures to stay in power. ${ }^{13}$ Prime Minister Liaquat Ali Khan made centralising the state bureaucracy his main task, especially after Jinnah's death in 1948. Pakistan's early instability, caused by a range of crises often involving its immediate neighbour states, made a seemingly compelling case for a centrist government:

There is no denying that the new state had enormous economic and social challenges, foremost being the settling of refugees who had poured into the country, mostly destitute and without resources. There were secessionist tendencies in NWFP [North-West Frontier Province, or Khyber Pakhtunkhwa as it has been known since 2010] politics that were being encouraged by the Afghan government and the lingering problem of Kashmir was ever present, making the security of the country vulnerable. The government, taking advantage of these issues, continuously relied on the Public Safety Act and other new draconian measures to keep a check on political opponents. ${ }^{14}$

In those difficult circumstances, the British and US intelligence agencies took it upon themselves to ensure that Liaquat Ali Khan's Government remained hostile toward communism. As a result, at least two secret state committees were formed in 1949 'to combat communism in government services' ${ }^{15}$ Early domestic studies, however, suggest that Pakistani political elites, while wary of the internal 'communist threat', had no intention at first to align themselves with either of the two superpowers. ${ }^{16}$ In 1949 ,

11 Mohammad Ayub Khan, Friends Not Masters: A Political Autobiography (Oxford University Press, 1967) 130. It is unlikely that General Ayub Khan, Pakistan's second President (1958-69) and the author of this unfortunate phrase, could anticipate it becoming the symbol of his state's overwhelming dependence on the United States.

12 Allen McGrath, The Destruction of Pakistan's Democracy (Oxford University Press, 1996) 52-3.

13 Ali, Communism in Pakistan, above n. 4, 121.

${ }^{14}$ Ibid., 122.

15 Ibid., 123.

16 Hafeez-ur-Rahman Khan, 'Pakistan's Relations with the USSR' (1961) 14 Pakistan Horizon 40; Mohammed Ahsen Chaudhri, 'Pakistan's Relations with the Soviet Union' (1966) 6 Asian Survey 492. 
Liaquat Ali Khan was invited to visit Moscow, but instead chose to travel to Washington the year after:

Why this change of plans occurred has never been satisfactorily answered by the Government of Pakistan ... However, Pakistan had no intention of having exclusive relations with the United States. While in the United States, Liaquat Ali Khan repeatedly stated that Pakistan had much to gain in the agricultural field through better relations with the Soviet Union. ${ }^{17}$

At the same time, in a political gesture similar to that made by Indian Prime Minister Jawaharlal Nehru in his address to the United States House of Representatives in October 1949, Liaquat Ali Khan used the publicity of his Washington visit to declare Pakistan's firm resolve 'to throw all her weight to help the maintenance of stability in Asia'. ${ }^{18}$ In these early days, far from vying for an open alliance with the United States, each of India and Pakistan sought to establish itself as a regional force in its own right.

That, however, was not to be. Pakistan, being the largest Muslim state with a leadership seemingly far more agreeable - in the crude words of the US Consul-General in Lahore - than the 'tortuous Hindu who despises as he grovels before, or politely infuriates by obfuscation the unclean European', ${ }^{19}$ appeared to the Truman administration to be an excellent candidate for a 'Northern Tier' collective defence arrangement against the Soviet Union and its allies, along with Turkey, Iran and Iraq. The advent of the Korean War, in June 1950, made such considerations central to an increasingly aggressive American foreign policy in Asia. Liaquat Ali Khan's condemnation of North Korean aggression seemingly 'decided American sympathy toward accommodating Pakistan', especially because Pakistan's official stance on the conflict between the two Koreas 'contrasted sharply with Nehru's adamant criticism of American policy in the Far East'.

In an insightful article, Hamza Alavi, Pakistan's Marxist sociologist and activist, claims that, in this crucial period, 'Pakistan felt isolated, as

17 Chaudhri, 'Pakistan's Relations with the Soviet Union', above n. 16, 493.

18 Robert J. McMahon, 'United States Cold War Strategy in South Asia: Making a Military Commitment to Pakistan 1947-1954' (1988) 75 Journal of American History 812, 821.

19 Doolittle to the Secretary of State, 4 September 1948, United States National Archives 845.00/9-448, box 5959, quoted in Ayesha Jalal, 'Towards the Baghdad Pact: South Asia and Middle East Defence in the Cold War, 1947-1955' (1989) 11 International History Review 409, 415.

${ }^{20}$ George J. Lerski, 'The Pakistan-American Alliance: A Reevaluation of the Past Decade' (1968) 8 Asian Survey 400, 401. 
a political orphan on the world stage, ${ }^{21}$ He recalls that Liaquat Ali Khan began his first major speech in the United States with the words that a country has 'no eternal friends and no eternal enemies. It has eternal interests' ${ }^{22}$ And the interest that Pakistan's political and military elites had long identified as first and foremost was to purchase arms from any willing foreign power and thus end its extreme military weakness; a direct consequence of India's non-compliance with the partition agreements relating to the armed forces'. ${ }^{23}$ With the Truman administration finally convinced (much to the dismay of the British) that the US's selfproclaimed neutrality with respect to the India-Pakistan tug-of-war had become untenable, and contrary to America's own larger Cold War interests in Asia, a road toward an otherwise-unlikely military alliance between the United States and Pakistan was opened. Crucially, 'it was the US that took the initiative and went to great lengths to manoeuvre support for it in Pakistan'. ${ }^{24}$

Apart from Pakistan's paranoia about its military shortcomings, a key reason for succumbing to Uncle Sam's Cold War advances seems to have been the sheer inadequacy of the country's 'international lawfare', to which this chapter now turns. In the early days of the global Cold War, international law played a particularly important role and was often indistinguishable, in method and ideological orientation, from other types of state-led international political intervention. Pakistan's inability to compete successfully in global 'cold lawfare' resulted in deep political frustrations, the consequences of which would be felt for many decades to come.

\section{Pakistan's International Lawyers' Underwhelming Coming of Age}

'It is hard to assess the role of Sir Zafrulla Khan', complains the wellinformed author of a book on Pakistan's contributions to international law, 'because he was perhaps the most laconic judge who ever sat at the World Court since the end of the Second World War. ${ }^{25}$ He goes on to

${ }^{21}$ Hamza Alavi, 'Pakistan-US Military Alliance' (1998) 33 Economic and Political Weekly $1551,1552$.

22 Ibid. Variations of this statement have been famously uttered by a number of political realists, including Klemens von Metternich, Viscount Palmerston, Charles de Gaulle and - perhaps inevitably - Henry Kissinger.

${ }^{23}$ Ibid.

${ }^{24}$ Ibid., 1551.

${ }^{25}$ Ijaz Hussain, Issues in Pakistan's Foreign Policy: An International Law Perspective (Progressive Publishers, 1988) 118. 
explain that during Sir Zafrulla's 'fifteen and half years of long stay there, he did not write more than 20 pages in the shape of individual opinions or declarations' and that 'before his elevation to the World Court he had neither been a practising jurist of international law nor an academician of the latter discipline. ${ }^{26}$ The author's account of Sir Zafrulla's life and times at the International Court of Justice is, nonetheless, largely positive, praising the judge's 'strictly functional approach to the cases before the Court $^{27}$ in a time of great ideological divisions (between the judicial proponents of Western, Soviet and Third World approaches to international law, respectively). But he could not help admitting that Sir Zafrulla's role - or, rather, the lack thereof - in 'the South-West Africa case of 1966 rendered him controversial and somewhat tarnished his image', ${ }^{28}$ especially in the eyes of the Third World:

The controversy arose when [Sir Zafrulla] failed to sit on the bench in the foregoing case with the result that it was decided in favour of South Africa by the casting vote of President Sir Percy Spender [of Australia] as the earlier vote resulted in a tie with seven judges in favour and seven against. In view of Sir Zafrulla's legal outlook and the fact of his belonging to the Third World, one can say with hindsight that with his participation in the case the judgment would have gone against South Africa. ${ }^{29}$

It later transpired that the Court's President had asked the Pakistani justice not to sit on the case because Sir Zafrulla had been nominated as an ad hoc judge by Ethiopia and Liberia before his having come to the International Court of Justice. Apparently, Sir Zafrulla chose to comply with this request 'because his eyes were fixed on the presidency of the World Court'. ${ }^{30}$

This was not an isolated case. Rather, Sir Zafrulla's 'lax and negligent ${ }^{31}$ behaviour sums up the unfortunate history of Pakistan's early engagements with international law. For instance, the country's contribution to the Sixth (Legal) Committee of the General Assembly of the United Nations has been described as 'meagre ${ }^{\text {,32 }}$ at best:

Although Pakistan has a vital interest in the development of the Law of the Sea, its representative to the Legal Committee did not take any active part

${ }^{26}$ Ibid.

27 Ibid., 121.

${ }^{28}$ Ibid., 129.

${ }^{29}$ Ibid., 129-30.

${ }^{30}$ Ibid., 134.

31 Ibid.

32 Mohammed Ahsen Chaudhri, Growth of International Law and Pakistan: A Collection of Essays (Inter Services Press, 1965) 99. 
in the discussion. On many other matters that were examined by the Legal Committee, such as the establishment of International Criminal Court, the Rights and Duties of States, and Reservations to Multi-lateral Conventions, the representative of Pakistan did not say much. ${ }^{33}$

By way of contrast, it appears that '[e]very noted scholar' of international law in India and that country's 'many senior civil servants' participated in and/or 'wrote extensively' about the law of the sea negotiations, ${ }^{34}$ convinced as they were that they could contribute substantially to this area of law's 'evolution and final shape'. ${ }^{35}$ It has been suggested that one of the reasons for Pakistan's markedly less prominent engagements with international law was its relatively early disillusionment with it. ${ }^{36}$ If this is true, one need not look far for examples of Pakistan's less-than-successful engagements with the international legal system; virtually every dispute with its neighbours that Pakistan initially tried to resolve by means of international law ran into seemingly insuperable difficulties.

Pakistan's two protracted territorial disputes, with Afghanistan over Khyber Pakhtunkhwa (or 'Pashtunistan', as called by the Afghans) and India over the former princely state of Jammu and Kashmir, respectively, left an indelible mark on its international affairs. Afghanistan, for example, was the only state to oppose the admission of Pakistan, on 30 September 1947, to the United Nations. ${ }^{37} \mathrm{~A}$ few months later, on the advice of Lord Louis Mountbatten, its Governor-General, India took the case of the Pakistani tribal invasion of Jammu and Kashmir (following the princely state ruler's signing an instrument of accession to India) to the United Nations Security Council. ${ }^{38}$ Pakistan saw Lord Mountbatten's involvement in this affair as deeply biased, given that the ruler of the predominately Muslim princely state was a Hindu. ${ }^{39}$ The Pakistani and Indian delegations 'traded charges against

${ }^{33}$ Ibid., 98.

34 B. S. Chimni, 'International Law Scholarship in Post-Colonial India: Coping with Dualism' (2010) 23 Leiden Journal of International Law 23, 37.

35 Ibid., 38.

36 Chaudhri, Growth of International Law and Pakistan, above n. 32, 99.

37 Sultana Afroz, 'Afghanistan in US-Pakistan Relations, 1947-1960' (1989) 8 Central Asian Survey 131, 136. Afghanistan later withdrew its oppositional vote.

38 See Rahul Roy-Chaudhury, 'The Security Council and the India-Pakistan Wars' in Vaughan Lowe et al. (eds.), The United Nations Security Council and War: The Evolution of Thought and Practice since 1945 (Oxford University Press, 2008) 324-45, 325.

39 It was this ruler, Maharaja Hari Singh, who sought Lord Mountbatten's help with the Pakistani tribal invasion in the first place and who - albeit reluctantly, given his initial hopes for Jammu and Kashmir's independence - signed, along with Lord Mountbatten, the instrument of accession to India. See Paul M. McGarr, 'Tinker, Tailor, Soldier, Subversive: India, Pakistan and the Politics of Cold War Intelligence' in Leslie James 
each other in the Council ${ }^{40}$ but all that kerfuffle resulted only in the lukewarm Resolution 38 calling on both sides in the conflict to immediately [take] all measures within their power (including public appeals to their people) calculated to improve the situation'. ${ }^{41}$ Thus began the two states' long engagement with the Security Council, which, if anything, 'resulted in a diplomatic stalemate between India and Pakistan'. ${ }^{42}$ Pakistan's dissatisfaction related particularly to the absence of the call for the conducting of a United Nations-supervised plebiscite in Jammu and Kashmir on whether to accede to Pakistan or India from later Security Council resolutions - a call central to early resolutions on the 'India-Pakistan Question' that India eventually managed to exclude due to its subsequent close relationship with the Soviet Union. ${ }^{43}$

It is with these early disappointments on the international scene and a continued stream of 'cold' and 'warm' conflicts in its borderlands - most notably the First Kashmir War (22 October 1947-1 January 1949) - that Pakistan entered the watershed year of 1951. Following the assassination of Liaquat Ali Khan on 16 October by an Afghan nationalist, the state's profound political crisis reached the point of no return. The subsequent regimes' decidedly anti-labour and anti-communist domestic outlook 'was partly due to [their] authoritarian character, but also due to the Pakistan Army's close alliance with the US' ${ }^{44}$ In the following part, I briefly examine the effects of this alliance on Pakistan's external legal and political Cold War affairs, particularly with regard to the non-aligned Third World.

\section{Pakistan Contracts Cold War 'Pactitis' but Finds Cure in China}

It was Secretary of State John Foster Dulles - the author of such aggressive US Cold War policies as 'rollback' and 'brinkmanship" ${ }^{45}$ - who first

and Elisabeth Leake (eds.), Decolonization and the Cold War: Negotiating Independence (Bloomsbury Academic, 2015) 285-302, 304.

${ }^{40}$ Ijaz Hussain, Kashmir Dispute: An International Law Perspective (S. T. Printers, 1998) 11.

41 SC Res 38, UN SCOR, 229th mtg, UN Doc. S/RES/38 (17 January 1948).

${ }^{42}$ Roy-Chaudhury, above n. 38, 332.

${ }^{43}$ In 1962, the Soviet Union vetoed for the first time a draft Security Council resolution referring to the plebiscite: see Report of the Trusteeship Council to the Security Council on the Trust Territory of the Pacific Islands covering the Period form 20 July 1961 to 16 July 1962, UN Doc. S/5143 (19 July 1962).

44 Ali, Communism in Pakistan, above n. 4, 16.

45 'Rollback' refers to the strategy to force major policy changes in a target state, usually by overthrowing its ruling regime. It was designed as the Republican answer to the Democrats' 
embarked on an extensive treaty-making crusade, which saw the United States form early Cold War alliances with forty-two nation states and treaty relations with nearly 100 of them, ${ }^{46}$ a state of affairs which has been described as 'pactomania' or 'pactitis'. ${ }^{47}$ Although the Soviet Union did not shy away from a 'treaty offensive' from time to time, ${ }^{48}$ the sheer scale of Dulles' 'pactitis' remained unparalleled.

Following the turmoil of Liaquat Ali Khan's assassination, Pakistan gradually contracted this disease as well. Even while the prime minister was still alive, attracted by the prospect of substantial American military aid, some of his army chiefs began contemplating an alliance with the United States, most notably General Ayub Khan ${ }^{49}$ who went on to stage Pakistan's first successful military coup d'état in 1958 and reign over the country for the next eleven years. Clandestine discussions between the two countries' military and political representatives finally resulted in a series of agreements signed in 1954 and 1955, with which Pakistan formally abandoned its policy of neutrality and non-involvement in the global Cold War:

In accordance with ... Dulles's 'Northern Tier Plan', Pakistan, Turkey and Iran (Pakistan, under direct US initiative and encouragement) signed an agreement of mutual cooperation with Turkey on 2 April 1954. The Turko-Pakistani Pact was followed by the Mutual Defence Assistance Agreement between the US and Pakistan on 19 May 1954. This ... placed Pakistan on a priority list so that 'special consideration' would be given to Pakistan in providing military assistance, including grants ... Pakistan's next steps in the direction of becoming America's Asian ally were its membership in the Southeast Asian Treaty Organisation (SEATO) in September 1954 and in the Baghdad Pact, later CENTO (Central Treaty Organisation), in July 1955. Thus, by 1955, Pakistan was associated with the US through not one, but four mutual security arrangements. ${ }^{50}$

'containment' approach, which sought to prevent the expansion of an enemy state. Dulles described his 'brinkmanship' policy as '[ $\mathrm{t}$ ] he ability to get to the verge without getting into the war': James Sheply, 'How Dulles Averted War', Life (16 January 1956) 70.

46 Cornelia Navari, Internationalism and the State in the Twentieth Century (Routledge, 2000) 316.

47 See, e.g., Lerski, above n. 20, 402.

48 Described by an unsympathetic commentator as Soviet 'efforts to enmesh the Western powers in treaties, agreements, and declarations which impose obligations on them to their detriment': George E. Glos, 'The Theory and Practice of Soviet International Law' (1982) 16 International Lawyer 279, 294.

49 Ayub Khan, then Commander-in-Chief of the Pakistani Army, arguably began to mull over a military alliance with the US in August 1951: Fazal Muqueem Khan, The Story of the Pakistan Army (Oxford University Press, 1963) 159.

${ }^{50}$ Afroz, above n. 37, 144-5. 
At the outset of this treaty crusade, Dulles calculated in a private memo to President Eisenhower that, although 'we must expect quite a storm from India if we go ahead with a military program for Pakistan', the administration could 'ride out the storm without fatal effect on US-Indian relations'. ${ }^{51}$ Indeed, although Nehru 'locked horns with the United States on a number of nagging bilateral issues in the aftermath of the Pakistani arms agreement', ${ }^{52}$ the intrinsic complexity of Cold War relations in $\mathrm{Asia}^{53}$ made this particular affair relative to a number of other regional developments, not least Pakistan's curious dealings with China.

While suffering from acute 'pactitis' with the United States a testament to its international lawyers' inability to wrestle a better deal and evidence of its military-cum-political chiefs' incapability to see beyond the country's perceived immediate security needs - Pakistan's diplomacy had the wit to 'simultaneously sen[d] positive signals to Beijing. ${ }^{54}$ Back in the first year of the decade, Pakistan was one of the first sovereign states to recognise the nascent People's Republic of China but hardly its proven ally in South Asia. Now, in 1954, Pakistan's diplomatic representative in Beijing brought to his Chinese communist counterparts a surprising message: 'Pakistan was seeking improved relations with China'. ${ }^{55}$ China's positive response created one of the Cold War's most idiosyncratic bilateral relations. That all this happened in $1954-$ the year in which the Communist Party of Pakistan was finally banned and its many prominent activists either jailed or exiled from the country is a testament to the ruthlessness of Cold War realpolitik everywhere, but also to the rise of Third-Worldism in its many Asian variants. ${ }^{56}$

${ }^{51}$ Dulles to Eisenhower in an undated memo, most likely written in January 1954, quoted in McMahon, 'US Policy toward South Asia and Tibet during the Early Cold War', above n. 10,137 .

${ }^{52}$ McMahon, 'US Policy toward South Asia and Tibet during the Early Cold War', above n. $10,138$.

${ }^{53}$ For an illuminating recent study, see generally Zheng Yangwen, Hong Liu and Michael Szonyi (eds.), The Cold War in Asia: The Battle for Hearts and Minds (Brill, 2010).

54 Paul J. Smith, 'The China-Pakistan-United States Strategic Triangle: From Cold War to the "War on Terrorism"' (2011) 38 Asian Affairs 197, 200.

${ }^{55}$ Ibid.

${ }^{56}$ China's increasing insistence in international relations on being itself seen as a Third World country and having no interest in becoming a superpower is a case in point and a direct consequence of its competition with the Soviet Union for the Third World. In pursuit of this long-term strategy, the Chinese were apparently willing to overlook internal anti-communist measures put in place by certain Third World countries such as Pakistan. See generally Jeremy Friedman, Shadow Cold War: The Sino-Soviet Competition for the Third World (University of North Carolina Press, 2015). 
For all these brave new configurations of power, the Asian-African Conference in April 1955 in Bandung, Indonesia became the key testing ground. Pakistan, one of the five Colombo Powers, ${ }^{57}$ co-sponsored and took an active part in the Bandung Conference, despite India's protestations. Ironically, neither Pakistan nor India were at first enthusiastic about this gathering. Nehru saw the involvement of SEATO members, including Pakistan, as highly problematic. Pakistan's Prime Minister Mohammad Ali Bogra, for his part, apparently thought ' $t \mathrm{t}]$ he whole thing was a waste of time' ${ }^{58}$ The Conference, nonetheless, proved to be an excellent opportunity to showcase both Pakistan's and India's (somewhat divergent) Third World credentials - especially with respect to China.

Nehru sought to gain further traction for his (short-lived) rapprochement with China's Premier Zhou Enlai over the Tibet question, leading to their 1954 Panchsheel Treaty (from Pali: panch - 'five', sheel - 'virtues'), at the centre of which were the so-called 'five principles of peaceful coexistence. ${ }^{59}$ Nehru's proposal in Bandung was to adopt these principles as a basis for Third World cooperation. In response, Mohammad Ali Bogra suggested that the delegates should consider Pakistan's 'seven pillars of peace' instead. ${ }^{60}$ Eventually, the Conference adopted a statement of ten principles. Bandung turned out to be a setback for both Nehru's and Bogra's international profiles; in their stead, 'the Chinese had hogged the limelight'. ${ }^{61}$ Premier Zhou Enlai 'displayed exemplary "reasonableness and peacefulness" and interceded for Nehru at various critical points'. ${ }^{62} \mathrm{He}$ also publicly acknowledged that Pakistan's membership in SEATO 'was not directed against China, but

57 Burma (later Myanmar), Ceylon (later Sri Lanka), India, Indonesia and Pakistan. A 1954 summit of the Colombo Powers, which proposed holding a large-scale international gathering of the newly independent states of Asia and Africa, led to the 1955 Bandung Conference.

58 That is, at least, what one of the secretaries to the Prime Minister intimated to the British High Commissioner in Pakistan on 6 December 1954, adding that 'it was a great mistake to let the Indonesians get away with this idea simply so that the present government of Indonesia could have an opportunity to aggrandize itself: Pang Yang Huei, 'The Four Faces of Bandung: Detainees, Soldiers, Revolutionaries and Statesmen' (2009) 39 Journal of Contemporary Asia 63, 69.

59 By virtue of this treaty, India accepted China's occupation of Tibet in 1950 and 1951. The similarity of the treaty's reference to 'peaceful coexistence' with the Soviet international legal doctrine of peaceful coexistence was not accidental. See ibid., 70.

${ }^{60}$ Ibid., 73.

${ }^{61}$ Ibid., 71.

62 Ibid. 
was defensive in nature. ${ }^{63}$ Bogra responded in kind, declaring that, unlike the Soviet Union, 'China is by no means an imperialist nation and she has no satellites'. ${ }^{64}$

However, China's conciliatory role was not meant to last for long. Sino-Indian relations quickly deteriorated over boundary issues and the Tibet question, escalating, in 1962, into a full-fledged war. Pakistan, on the other hand, saw its relations with China flourish to an unprecedented scale. In 1961, Pakistan voted to admit the People's Republic of China into the United Nations and counted as the only US ally consistently supporting China's official positions on Tibet and Taiwan. In 1963, Pakistan and China reached a border agreement on Kashmir, despite the ongoing territorial dispute between Pakistan and India. At the same time, Pakistan strongly supported the idea of 'a second Bandung meeting' (planned for Algiers in 1965) and 'had made it clear that it would try and use this forum to promote the need for new and binding mechanisms outside the United Nations system to resolve international disputes ${ }^{65}$ including, presumably, that in Kashmir. All these developments greatly disturbed India. Its industrious diplomatic wrangles ensured that there would be no 'second Bandung' and that Pakistan would be reliably absent from both the initial 1961 Belgrade Conference of Non-Aligned States and their subsequent 1965 Conference in Cairo. ${ }^{66}$

It was, however, impossible to foil Pakistan's participation in the Tricontinental Conference of Solidarity of the Peoples of Africa, Asia and Latin America, held in Havana in January 1966. It is there that Pakistan's alliance with China became most obvious. The two countries joined efforts to prevent the Soviet delegate (who was supported by India) from inserting 'peaceful coexistence' into the conference's general political resolution. In addition, the Chinese press was full of praise for the Pakistani delegate, who joined the chorus of critical remarks about the United Nations with the following observation:

The United Nations is still being dominated and utilized by the imperialist powers. It continues to deprive the Chinese people of their legitimate seat in that organization. Its intervention in Korea, Pakistan, Kashmir and the

${ }^{63}$ Smith, above n. 54, 200.

64 Itty Abraham, 'From Bandung to NAM: Non-Alignment and Indian Foreign Policy, 1947-65' (2008) 46 Commonwealth \& Comparative Politics 195, 205.

65 Ibid., 212.

66 Ibid., 211-14. See also W. M. Dobell, 'Pakistan's Relations with the Major Powers and Some Minor Agreements' (1964) 37 Pacific Affairs 384, 384 and 389. 
Congo (L) has complicated matters in these places and this is only beneficial to the imperialists and colonialists. ${ }^{67}$

Both the Soviet and Indian delegates sought to avoid direct criticism of the United Nations and fought - ardently but unsuccessfully - to erase any mention of it in the Conference's general political resolution. Thus, the resolution's final text condemned the United Nations for both 'having allowed itself to be used more than once by U.S. imperialism' and for 'having deprived the People's Republic of China of its legitimate seat in this organization'.68

It would be short-sighted to consider the Sino-Pakistani love affair solely in light of Pakistan's perennial disputes with India, or, indeed, the simultaneous breakdown of both Indian and Soviet relations with China. ${ }^{69}$ One of the most intriguing aspects of the affair is the United States' seemingly untroubled stance toward it. For although the US diplomats stationed in Pakistan had occasionally sent alarming letters to Washington, underscoring the need 'to keep Pakistan from becoming dependent upon or allied with Red China, ${ }^{70}$ the United States evidently saw this risky coalition at least partly beneficial for US Cold War interests, especially its own near-rapprochement with China. Thus, it was Pakistan that in the late 1960s 'secretly opened up a communication channel between the United States and China', ${ }^{71}$ which culminated, in 1971, in National Security Advisor Henry Kissinger's clandestine diplomatic visit to Beijing.

\section{Pakistan's Turning Left, Then Right, Only to Witness the Soviet Swan Song}

The year 1971 also saw the Government of Pakistan's momentous but short-lived turn Left, under the leadership of the state's President (1971-3) and then Prime Minister (1973-7) Zulfikar Ali Bhutto. Although far from seeing through the 'socialist' reforms he initially promised, ${ }^{72}$ Bhutto devised a new approach to his country's Cold War

${ }^{67}$ Xinhua Correspondent (anonymous), 'Report from Havana: The First Afro-Asian-Latin American Peoples' Solidarity Conference' (1966) 9(4) Peking Review 19, 23.

${ }^{68}$ Ibid.

69 On the latter, see Vojtech Mastny, 'The Soviet Union's Partnership with India' (2010) 12 (3) Journal of Cold War Studies 50.

70 US Department of State, 'Ambassador Eugene M. Locke Lists US Objectives in Pakistan' (Memorandum, 26 July 1966) quoted in Smith, above n. 54, 202.

${ }^{71}$ Ibid., 199.

72 'Instead of delivering on his electoral promises of egalitarian democracy and workers' rights once in power, Bhutto brutally crushed the radicalized labor movement and 
affairs, advocating Third-Worldist 'bilateralism' with 'each of the great powers', which sought to identify 'areas of cooperation with one without repudiating an alliance with another and thus evolving an internally consistent and integrated policy. ${ }^{73}$ Guided by this new approach, Pakistan withdrew from SEATO, while also becoming a key member of the Organisation of the Islamic Conference (OIC, later Organisation of Islamic Co-operation). When CENTO was disbanded, following the 1979 Revolution in Iran, Pakistan also formally joined the Non-Aligned Movement (NAM).

In the sea of changes, China remained Pakistan's trusted lifeboat. In June 1976, a few months before his death, Chairman Mao Zedong promised Bhutto during an intimate meeting in Beijing that China would help Pakistan build its own atomic bomb. ${ }^{74}$ Bhutto, 'long an unapologetic advocate of a Pakistan bomb ${ }^{75}$ worked tirelessly with his Chinese counterparts to see this promise delivered. The ensuing SinoPakistani nuclear partnership saw Pakistan develop nuclear capability on a par with India. At the same time, emboldened by their strategic partnerships with China and the Soviet Union, respectively, both Pakistan and India refused to "participate meaningfully ${ }^{76}$ in international legal and diplomatic efforts aimed at curbing nuclear proliferation. Instead, the nuclear arms race between India and Pakistan became - and still remains - one of the staples of the two countries' troubled relations, bearing as it is all the hallmarks of a 'cold' war of their own.

It may be ironic that Pakistan's only 'socialist' president and prime minister oversaw the country's full transition into a regional Cold War power in its own right. However, the irony was lost on the United States, which saw Pakistan's new position as increasingly problematic and dangerous to its own Cold War interests in Asia. Therefore, when Bhutto was deposed in a military coup d'état in July 1977 and executed, after a controversial trial, less than two years later, the United States saw no reason to intercede on his behalf. If anything, it is clear that the coup leader, General Muhammad Zia-ul-Haq, obtained tacit support from the

instituted labor policies that primarily strengthened the state's penetration of trade union politics': Yunas Samad and Kamran Asdar Ali, 'Labor in Pakistan' (2000) 58 International Labor and Working-Class History 314, 314.

73 Zulfikar Ali Bhutto, 'Bilateralism: New Directions' (1976) 29 Pakistan Horizon 3, 3.

${ }^{74}$ Mastny, above n. 69, 73.

75 Stuart W. Leslie, 'Atomic Structures: The Architecture of Nuclear Nationalism in India and Pakistan' (2015) 31 History and Technology 220, 235.

76 Samina Ahmed, 'Security Dilemmas of Nuclear-Armed Pakistan' (2000) 21 Third World Quarterly 781, 787. 
US for his ensuing eleven-year long dictatorial rule over Pakistan very early on. ${ }^{77}$ Soon after coming to power, Zia introduced a series of domestic legal and social 'Islamisation' reforms ${ }^{78}$ and strengthened Pakistan's cooperation and ideological ties with Muslim states, most notably the OIC.

That the Carter administration had turned a blind eye to Zia's decisively right-wing politics had much, if not all, to do with the emerging USSoviet proxy war in Afghanistan. ${ }^{79}$ Just four days after the Soviets' misguided and ultimately self-destructive invasion of Afghanistan on 24 December 1979, President Carter telephoned Zia to inform him that 'he was reviewing ways the United States could help counter the Soviet threat to Pakistan and assured him of the American government's support. ${ }^{80}$ That Carter chose to couch the Soviet invasion of Afghanistan in terms of an imminent threat to Pakistan was not insignificant. With the Soviet Union becoming Pakistan's de facto neighbour state, the US intelligence actively sought to promote the idea of an 'Islamic barrier against the Soviets' ${ }^{\prime 81}$ and saw Zia's Islamic reforms as fortuitous. General Zia, for his part, regarded the Soviet invasion of Afghanistan as an extraordinary opportunity to gain both domestic and foreign support. ${ }^{82}$ Thus, the hitherto clandestine US-Pakistani rapprochement entered an overt phase - a phase that, under the Reagan administration, led to Pakistan's full military and diplomatic emersion in the Soviet-Afghan War.

The Soviet withdrawal from Afghanistan, in 1989, constituted, arguably, one of the final episodes of the global Cold War and contributed significantly to the 1991 disintegration of the Soviet Union. ${ }^{83}$ However, both 'cold' and 'warm' wars continued to beset Pakistan. The centrality of those and earlier conflicts involving Pakistan to global political and legal

77 See generally Omar Noman, 'Pakistan and General Zia: Era and Legacy' (1989) 11 Third World Quarterly 28. It is a dominant - but as yet unproven - view of the Pakistani Left that the United States was not just a passive bystander to Zia's 1977 coup d'état.

${ }^{78}$ For a critique of these reforms, see Vanja Hamzić, 'Pakistan' in Ziba Mir-Hosseini and Vanja Hamzić, Control and Sexuality: The Revival of Zina Laws in Muslim Contexts (WLUML, 2010) 154.

79 See, e.g., Farida Shaheed, 'Contested Identities: Gendered Politics, Gendered Religion in Pakistan' (2010) 31 Third World Quarterly 851, 854.

${ }^{80}$ Christopher Van Hollen, 'Leaning on Pakistan' (1980) 38 Foreign Policy 35, 35.

${ }^{81}$ Shaheed, above n. $79,854$.

82 Nasreen Akhtar, 'Pakistan, Afghanistan, and the Taliban' (2008) 25(4) International Journal on World Peace 49, 53.

${ }^{83}$ See generally Rafael Reuveny and Aseem Prakash, 'The Afghanistan War and the Breakdown of the Soviet Union' (1999) 25 Review of International Studies 693. 
affairs questions not only the country's place in past Cold War geographies; they are a living proof that the global Cold War, despite the Soviet demise and the emergent 'post-socialist' polities in Europe and elsewhere, may not have ended at all.

\section{Conclusion: Pakistan's Orwellian Future Past}

Except for its affective quality - capturing the frostiness of international relations bogged down in the perpetual superpower impasse - the 'Cold War', as a term-of-art, makes little sense. If anything, it demonstrates a perfidious tendency in Western scholarship to describe as 'stable' or even 'peaceful' ${ }^{84}$ the period in world history that saw superpower competition and other ostensibly 'non-violent' international affairs result in 'over a hundred wars through the Third World and a body count of over 20 million' ${ }^{85}$ In this period, Pakistan and India alone fought three 'warm' wars with each other and faced numerous military crises short of open conflict. Moreover, both 'warm' and 'cold' skirmishes between the two states continued to occur well after 1989, including, most notably, Indian nuclear tests in May 1998 duly reciprocated by Pakistan a couple of weeks later. To think of the Cold War as a period in which diplomatic, and indeed legal, efforts centred chiefly on superpower relations short of open warring means, then, to perpetuate - as Antony Anghie and B. S. Chimni remind us with respect to international law - an epistemic 'violence that thinks of itself as kindness'. ${ }^{86}$

At the same time, as this chapter has shown, specifically Cold War relations - both with the two superpowers and a range of other states, not least its immediate neighbours - have defined much of Pakistan's postpartition history. Having 'dealt with' the state's progressive intelligentsia very early on, Pakistan’s political and military elites gradually succeeded

${ }^{84}$ For example, John Lewis Gaddis had the audacity to suggest that this long 'period of stability in relations among great powers' should not be called 'the Cold War' but 'a rare and fondly remembered "Long Peace"': John Lewis Gaddis, The Long Peace: Inquiries into the History of the Cold War (Oxford University Press, 1987) 216, 245.

${ }^{85}$ Andrew Hammond, 'From Rhetoric to Rollback: Introductory Thoughts on Cold War Writing' in Andrew Hammond (ed.), Cold War Literature: Writing the Global Conflict (Routledge, 2006) 1.

${ }^{86}$ Antony Anghie and B. S. Chimni, 'Third World Approaches to International Law and Individual Responsibility in Internal Conflicts' (2003) 2 Chinese Journal of International Law 77, 102. The authors attribute this phrase to Zygmaunt Bauman but use it to denounce approaches to international law that 'fail to take into account its violent origins'. 
in establishing and maintaining the kinds of Cold War relations, such as military partnerships, that would primarily ensure a domestic political, class and military status quo. As a result, for most of the Cold War years, Pakistan was governed by unelected leaders, with two long spells (1958-71, 1977-88) of direct military rule. Even the country's democratically elected leaders sought to develop a predominantly inward-looking foreign policy, such as Zulfikar Ali Bhutto with his quest for Pakistan's own atomic bomb. Global and regional Cold War relations helped Pakistan's elites not only to maintain their sway over the country's internal affairs; they also provided a necessary context in which it could be said that the country was in a perpetual crisis - a crisis that seemingly 'warranted' extraordinary measures, including rule by martial law, on an almost permanent basis.

It is, then, no surprise that an inward-looking foreign policy has paid little to no attention to international law, save when it meant a quid pro quo show of support to a partner state or coalition of states. The early loss of hope that international law could bring an end to any 'cold' or 'warm' conflict in Pakistan's borderlands seems to have spurred the state's crafty and reserved dealings with the international legal system, all the while setting out Pakistani international lawyers and diplomats on a quest to find an alternative to Cold War international law - be it the NAM or the OIC or some other multi-state formation. Along this path, Pakistan gradually acquired a type of Machiavellian international legal and political expertise, devoid of any particular ideology in its core (even when vying for a holier-than-thou position among the Muslim states) ${ }^{87}$ other than the constant need for the ruling classes' self-preservation. This expertise is arguably still widely employed, by Pakistan and other states, to produce and maintain Cold War-like relations and phenomena (think, for example, South Asia's own 'Checkpoint Charlie' on the Wahga crossing between Pakistan and India) ${ }^{88}$ even after the demise of the Soviet Union.

Due to this enduring Cold War legacy, Pakistan often relives its own Orwellian future past - a constant loop of events and circumstances in which Cold War-like elites prolong indefinitely a 'peace that is no peace'

87 was born on 14 August 1947?' - the day of Pakistan's independence: Jalal, 'Towards the
Baghdad Pact', above n. 19, 423 .

88 This crossing, known as Wagah in India, is a home to a daily lowering of the flags military ceremony, jointly coordinated by the Pakistani and Indian armies since 1959. The ceremony has since developed into a fast-paced and aggressive dance-like spectacle. 
for the sake of their own survival. ${ }^{89}$ Simultaneously, be they 'terrorist assemblages' ${ }^{\prime 90}$ or some other constellations of predominantly 'cold' yet constant warfare, some of the crises that now befall Pakistan and much of the rest of the world are also a testament to international law's distinctly post-Cold War (and perhaps final) evolution into a pure instrument of power $^{\text {'91 }}$ - an Orwellian phase in its own right in which the violence of international law $^{92}$ is plain to see.

89 Cf. George Orwell, 'You and the Atom Bomb' in George Orwell, The Collected Essays, Journalism and Letters of George Orwell: Volume VI, In Front of Your Nose, 1945-1950 Sonia Orwell and Ian Angus (eds.) (Secker and Warburg, 1968) 10. It is to this essay that the origins of the term 'Cold War' are often traced, despite it being employed as early as 1938 to describe the Sitzkrieg in Editorial, 'Hitler's Cold War' The Nation (26 March 1938) $345-6$.

90 To borrow a helpful phrase, denoting a discursive repository of power, from: Jasbir K. Puar, Terrorist Assemblages: Homonationalism in Queer Times (Duke University Press, 2007).

91 M. Sornarajah, 'Power and Justice: Third World Resistance in International Law' (2006) 10 Singapore Year Book of International Law 19, 56.

92 See generally Vanja Hamzić, 'International Law as Violence: Competing Absences of the Other' in Dianne Otto (ed.), Queering International Law: Possibilities, Alliances, Complicities, Risks (Routledge, 2017) 77. 